\title{
Analisis Kesalahan Berbahasa Indonesia Dalam Proses Diskusi Siswa Sekolah Dasar
}

\author{
Gio Mohamad Johan \\ Universitas Negeri Surabaya \\ giomjohan@gmail.com
}

How to cite (in APA Style): Johan, G.M. (2018). Analisis kesalahan berbahasa Indonesia dalam proses diskusi siswa sekolah dasar. Jurnal Pendidikan Bahasa dan Sastra, 18(1),136-149, doi: 10.17509/bs_jpbsp.v18i1.12153

Article History: Received (September 21,2017); Revised (January 14,2018);Accepted (February 12,2018).

Journal homepage: http://ejournal.upi.edu./index.php/BS_JPBSP

\begin{abstract}
Abstrak: Penelitian ini bertujuan untuk mendeskripsikan kesalahan berbahasa Indonesia yang dilakukan siswa kelas VI SDN 1 Galagamba. Penelitian ini menggunakan jenis deskriptif. Sumber data dalam penelitian ini adalah siswa kelas VI SDN 1 Galagamba. Instrumen yang digunakan dalam penelitian ini antara lain lembar observasi dan alat perekam. Teknik analisis yang digunakan dalam menganalisis data kesalahan berbahasa yakni teknik analisis data kualitatif. Hasil penelitian ini menunjukkan bahwa terdapat kesalahan berbahasa Indonesia meliputi kesalahan secara fonologis, morfologis, sintaktis, semantis, kohesi, koherensi, dan logika dalam proses diskusi yang dilakukan siswa sekolah dasar. Saran dari penelitian ini, guru dapat menggunakan hasil analisis mengenai kesalahan berbahasa yang dilakukan oleh siswa sebagai bahan refleksi pembelajaran.
\end{abstract}

Kata kunci: analisis kesalahan berbahasa, diskusi, siswa sekolah dasar.

\section{Language Error Analysis in Indonesian Primary School Student in Discussion Process}

\begin{abstract}
This study aims to describe the mistake of speaking in Indonesia done sixth grade at primary school of Galagamba. This research is a descriptive type. The source of the data in this study are students of sixth grade primary school of Galagamba. The instruments used in this research include observation sheets and recording device. Analytical techniques used in analyzing data error-language i.e. qualitative data analysis techniques. The results of this research show that there were errors in using Indonesian, which include phonological, morphological, sintactical, semantic, cohesion, coherence, and logic in the process of discussions performed by elementary school students. The advice of this research, the teacher can use the results of the analysis on language errors made by students as reflection of learning.

Keywords: language error analysis, discussion, elementary school students.
\end{abstract}




\section{PENDAHULUAN}

Bangsa Indonesia memiliki kebudayaan yang beraneka ragam. Bahasa merupakan salah satu cermin kebudayaan suatu bangsa. Keadaan ini membuat orang Indonesia mengenal dan menguasai lebih dari satu bahasa. Mereka setidaknya mengenal bahasa daerah dan bahasa Indonesia. Hal ini tentu tidak menutup kemungkinan munculnya kesalahan berbahasa Indonesia yang diakibatkan oleh adanya pengaruh bahasa daerah terhadap bahasa Indonesia.

Hastuti (2003,p.18) mengungkapkan bahwa seseorang yang mempunyai kemampuan menggunakan dua bahasa secara berganti-ganti disebut dwibahasawan. Berkaitan dengan hal itu, Pranowo (2014,p.103) juga mengemukakan bahwa masyarakat Indonesia pada umumnya tergolong masyarakat dwibahasa. Sebagian besar masyarakat Indonesia menguasai bahasa pertama (B1) bahasa daerah dan bahasa kedua (B2) bahasa Indonesia.

Lado (dalam Chaer dan Agustina, 2010,p.86) mengemukakan bahwa kedwibahasaan sebagai kemampuan menggunakan bahasa oleh seseorang dengan sama baik atau hampir sama baiknya, yang secara teknis mengacu pada pengetahuan akan dua bahasa. Sedangkan menurut Weinreich (1970,p.1) menitikberatkan pengertian kedwibahasaan bukan pada kefasihan penguasaan dua bahasa yang sama baiknya, melainkan pada kemampuan praktik menggunakan dua bahasa secara bergantian dalam berkomunikasi.

Pendapat lain muncul dari Bloomfield dalam bukunya yang berjudul language (1933,p.56) yang mengungkapkan bahwa kedwibahasaan adalah kemampuan seorang penutur untuk menggunakan dua baahsa dengan sama baiknya. Jadi menurutnya, seseorang dapat disebut bilingual atau dwibahasa apabila dapat menggunakan bahasa pertama dan bahasa keduanya dengan derajat yang sama baiknya.

Menurut Suwito (1983,p.40), pengertian tentang kedwibahasaan sebagai salah satu dari masalah kebahasaan terus mengalami perkembangan. Hal ini disebabkan oleh pengertian kedwibahasaan yang bersifat nisbi atau relatif. Kenisbian terjadi karena batasan seseorang untuk bisa disebut sebagai dwibahasawan sehingga pandangan tentang kedwibahasawan berbeda antara yang satu dengan yang lain. Berdasarkan beberapa pengertian sebelumnya, dapat ditarik kesimpulan bahwa kedwibahasaan merupakan kemampuan menggunakan dua bahasa yang dimiliki oleh seseorang dengan sama baiknya atau mengacu pada pengetahuan akan dua bahasa sekaligus. Akan tetapi akibat dari adanya masyarakat yang dwibahasa bahkan multibahasa itu dapat menimbulkan suatu fenomena bahasa yang disebut interferensi. Hal tersebut juga dapat menyebabkan terjadinya kesalahan berbahasa.

Hubungan yang terjadi antara kedwibahasaan dan interferensi sangat erat terjadi. Interferensi dapat dipandang sebagai akibat dari fenomena kedwibahasaan. Hal ini dapat dilihat pada kenyataan pemakaian bahasa dalam kehidupan sehari-hari. Situasi kebahasaan masyarakat tutur bahasa Indonesia setidaknya ditandai dengan pemakaian lebih dari satu bahasa, yaitu bahasa daerah sebagai bahasa pertama (B1) dan bahasa Indonesia sebagai bahasa kedua (B2). Meskipun pada pemakaiannya banyak pula masyarakat yang menjadikan bahasa Indonesia sebagai bahasa pertama dan bahasa daerah sebagai bahasa kedua.

Situasi pemakaian dengan beberapa bahasa seperti ini dapat memunculkan kontak antarbahasa. Berkaitan dengan hal tersebut Suwito (1985,p.39-40) mengungkapkan bahwa apabila dua bahasa atau lebih digunakan secara bergantian oleh penutur yang sama, dapat dikatakan bahwa bahasa tesebut dalam keadaan saling kontak. Dalam setiap kontak bahasa terjadi proses saling mempengaruhi antara bahasa satu dengan bahasa yang lain.

Bahasa pertama (B1) yang dikuasai terlebih dahulu, mempunyai pengaruh yang kuat terhadap pemakaian bahasa kedua (B2), dan sebaliknya bahasa kedua (B2) juga memunyai pengaruh yang besar terhadap pemakaian bahasa pertama (B1). Peristiwa 
semacam ini dapat menimbulkan interferensi. Lebih lanjut lagi Alwasilah (1985,p.132) mengungkapkan bahwa interferensi berrati adanya saling pengaruh antarbahasa. Pengaruh itu dalam bentuk yang paling sederhana berupa pengambilan satu unsur dari satu bahasa dan digunakan dalam hubungannya dengan bahasa lain.

Kesalahan berbahasa akan selalu ada, terutama bagi mereka yang sedang belajar bahasa. Sebagai suatu proses, pembelajaran bahasa dinilai sangat wajar apabila ditemui kesalahan di dalamnya. Hal tersebut sejalan dengan pendapat Dulay, et all. (dalam Yulianto dan Mintowati, 2010,p.53) yang mengemukakan bahwa orang tidak mungkin dapat mempelajari bahasa tanpa membuat kesalahan. Oleh karena itu, kesalahan merupakan suatu kewajaran atau sesuatu yang tidak terhindarkan dalam belajar bahasa.

Kesalahan berbahasa dapat terjadi dalam setiap tataran linguistik. Kesalahan berbahasa yang paling umum terjadi akibat penyimpangan kaidah bahasa. Kesalahan berbahasa secara sederhana dimaknai sebagai penggunaan bahasa, baik dilakukan secara lisan maupun tertulis yang menyimpang dari kaidah berbahasa. Hal tersebut sejalan dengan pendapat Tarigan (1988,p.272), yang mengungkapkan bahwa kesalahan merupakan sisi yang mempunyai cacat pada ujaran atau tulisan sang pelajar. Melengkapi pernyataan di atas, Dulay, et al. (1982,p.277) mengungkapkan kesalahan adalah bagian konversasi atai komposisi yang menyimpang dari beberapa norma baku (atau norma terpilih) dari performansi bahasa orang dewasa. Kesalahan berbahasa yang dilakukan siswa dianggap sebagai suatu hal yang wajar, akan tetapi hal tersebut harus dikurangi sampai ke batas minimal. Hal tersebut tentu baru dapat dilakukan apabila guru mampu menganalisis kesalahan tersebut secara cermat dan mendalam.

Analisis kesalahan berbahasa dapat dipandang sebagai suatu rangkaian aktivitas dalam mengumpulkan, mengidentifikasi, mengklasifikasi, menjelaskan, dan mengevaluasi kesalahan berbahasa. Hal itu sejalan dengan pendapat Tarigan dan Sulistiyaningsih (dalam Setiawati, 2010,p.18) yang mengungkapkan bahwa analisis kesalahan berbahasa adalah suatu prosedur kerja yang biasa digunakan oleh peneliti atau guru bahasa, meliputi: kegiatan mengumpulkan sampel kesalahan, mengidentifikasi kesalahan yang terdapat dalam sampel, menjelaskan kesalahan tersebut, mengklasifikasi kesalahan, dan mengevaluasi taraf keseriusan kesalahan itu.

Secara sederhana analisis kesalahan berbahasa dapat dilakukan oleh guru terhadap kesalahan siswa yang belajar bahasa. Dalam pelaksanaannya, analisis kesalahan berbahasa diharapkan memberikan deskripsi secara lengkap mengenai kesalahan berbahasa yang dilakukan oleh pembelajar. Sehingga, melalui informasi yang lengkap tersebut akan memberikan manfaat pedagogis yang berarti bagi pembelajaran. Sejalan dengan hal tersebut, Corder (dalam Yulianto dan Mintowati, 2010,p.53) mengungkapkan bahwa analisis kesalahan berbahasa mempunyai dua fungsi, yakni fungsi teoretis dan fungsi praktis. Fungsi teoretis analisis kesalahan berbahasa merupakan bagian dari metodologi penelitian proses belajar bahasa. Sementara itu, fungsi praktis analisis kesalahan berbahasa adalah memandu tindakan remedial dalam pengajaran bahasa.

Kesalahan berbahasa yang dilakukan oleh siswa dapat terjadi dalam berbagai bidang dan hal tersebut merupakan sesuatu yang wajar terjadi. Kesalahan berbahasa dapat terjadi dalam berbagai bidang, baik bahasa tulis maupun lisan. Kesalahan berbahasa dikelompokan ke dalam beberapa kategori tertentu untuk mempermudahkan penjabarannya.

Dalam melaksanakan analisis kesalahan berbahasa terdapat beberapa langkah kerja atau prosedur yang harus dilakukan. Proses analisis kesalahan akan mencakup kegiatan mendata dan mengklasifikasikan jenis kesalahan yang dilakukan oleh siswa. Dalam hal ini Dulay, et al. (1982,p.277) mengungkapkan bahwa analisis kesalahan merupakan suatu upaya 
mendata dan mengklasifikasi kesalahan yang terkandung dalam tuturan dan tulisan siswa. Hal tersebut menandakan adanya rangkaian proses yang dilakukan dalam tahap analisis berbahasa.

Analisis kesalahan berbahasa hendaknya dapat dilakukan secara cermat dan mendalam. Berkaitan dengan hal tersebut Tarigan (1989,p.9) mengungkapkan langkah-langkah kerja dalam analisis kesalahan berbahasa: (1) pengumpulan sampel kesalahan; (2) pengidentifikasian kesalahan; (3) penjelasan kesalahan; (4) pengklasifikasian kesalahan; dan (5) pengevaluasian kesalahan. Melengkapi pendapat sebelumnya, Ellis (1986,p.51-52) menambahkan beberapa langkah dalam analisis kesalahan berbahasa, yaitu (1) mengumpulkan korpus; (2) mengidentifikasi kesalahan; (3) mengklasifikasi kesalahan; (4) menjelaskan kesalahan; dan (5) mengevaluasi kesalahan.

Melengkapi pendapat sebelumnya, Sridhar (dalam Yulianto dan Mintowati, 2010,p.53) yang mengungkapkan ada enam langkah prosedur analisis kesalahan berbahasa, yakni (1) pengumpulan data; (2) identifikasi data; (3) klasifikasi data; (4) penentuan frekuensi kesalahan; (5) identifkasi wilayah kesulitan dalam belajar bahasa kedua; dan (6) terapi terhadap kesalahan.

Diskusi memungkinkan adanya dialog antara siswa dengan siswa maupun siswa dengan guru. Diskusi dapat dipandang sebagai suatu kegiatan komunikasi dua arah. Sejalan dengan pendapat sebelumnya, Arends (2001,p.378) mengungkapkan diskusi kelas merupakan komunikasi seseorang berbicara satu dengan yang lain, saling berbagi gagasan dan pendapat untuk mengekspresikan pikiran tentang pokok bahasan tertentu. Dalam hal ini diskusi dapat dipandang sebagai suatu model pembelajaran, dapat pula dipahami sebagai bagian atau tahapan dari model pembelajaran yang lain.

Melengkapi pendapat sebelumnya, Arends (1997,p.201) mengungkapkan bahwa diskusi digunakan oleh guru untuk mencapai sedikitnya tiga tujuan pembelajaran yakni, (1) memperbaiki pemikiran siswa dan membantu mereka mereka menyusun pemahaman materi akademis, (2) mendorong keterlibatan dan keikutsertaan siswa. Diskusi memberi kesempatan luas kepada siswa untuk mengutarakan dan bermain dengan ide-ide mereka sendiri, serta memotivasi siswa untuk ikut terlibat dalam pembicaraan di kelas, dan (3) membantu siswa belajar keterampilan komunikasi dan proses berpikir.

Fenomena kesalahan berbahasa dapat terjadi pada situasi atau bidang-bidang tertentu terutama pada pemakaian bahasa yang tidak hanya mengutamakan faktor komunikatif sebagai hasil akhir dalam aktivitas berbahasa, tetapi juga memperhatikan kaidah berbahasanya. Penguasaan terhadap bahasa Indonesia jelas diperlukan dalam interaksi belajar mengajar di sekolah. Tentunya di dalam lingkungan pendidikan, bahasa Indonesia yang digunakan adalah bahasa yang baik dan benar sesuai dengan kaidah berbahasa.

Proses belajar mengajar di sekolah merupakan salah satu situasi resmi yang menuntut adanya keteraturan kaidah berbahasa dengan baik dan benar. Berkaitan dengan pernyataan tersebut, Arifin dan Hadi (2001,p.12) mengungkapkan bahwa bahasa Indonesia yang baik dan benar adalah bahasa Indonesia yang digunakan sesuai dengan norma kemasyarakatan dan sesuai kaidah bahasa Indonesia yang berlaku. Akan tetapi, pada kenyataannya siswa selama di sekolah masih belum sepenuhnya menggunakan bahasa Indonesia dengan baik dan benar. Kesalahan berbahasa merupakan suatu hal yang tidak perlu ditakuti atau bahkan dihindari oleh guru, melainkan sesuatu yang perlu dihadapi dengan bijak dan menganggap hal tersebut sebagai suatu proses yang wajar terjadi terutama pada siswa yang sedang belajar bahasa. Hal tersebut sejalan dengan pendapat Corder (dalam Yulianto dan Mintowati, 2010,p.53) yang mengemukakan bahwa pada setiap 
orang yang belajar bahasa pastilah pernah melakukan kesalahan.

Suandi (dalam Purnamayani, 2014,p.3) mengungkapkan bahwa dalam berbahasa, hampir setiap orang pernah membuat kesalahan atau penyimpangan. Penyimpangan itu dapat dianggap sebagai usaha belajar apabila seseorang mau memahami kesalahankesalahan itu dan mau memanfaatkannya sebagai umpan balik dalam rangkameningkatkan kualitas berbahasanya. Meskipun demikian, kesalahan tersebut secara perlahan harus dikurangi intensitasnya. Guru jangan sampai merasa jenuh untuk membantu siswa mengatasi kesalahan tersebut. Kesalahan yang sering dibuat oleh siswa harus dikurangi dan kalau dapat dihapuskan sama sekali. Hal ini baru dapat dicapai kalau selukbeluk kesalahan itu dikaji secara cermat dan mendalam (Tarigan, 1989,p.8).

Berikut contoh kalimat yang terdapat kesalahan berbahasa di dalamnya, "Bencana tanah longsor membuat jalan ketutup tanah sama batu". Berdasarkan contoh kesalahan berbahasa tersebut, dapat diketahui bahwa kalimat di atas merupakan suatu kalimat yang tidak sesuai dengan kaidah berbahasa. Kesalahan ini dapat tergolong kesalahan berbahasa pada tataran morfolgis dan sintaksis. Kesalahan secara morfologis terletak pada kesalahan penggunaan afiks yang tidak tepat. Kesalahan tersebut disebabkan penggantian prefiks ter- menjadi ke-. Dalam bahasa Indonesia tidak ada prefiks ke-. Prefiks tersebut merupakan prefiks dalam bahasa daerah yang digunakan oleh siswa ke dalam bahasa Indonesia. Kesalahan secara sintaktis terletak pada kesalahan penggunaan konjungsi yang ditemukan dalam kalimat tersebut. Siswa menggunakan kata sama sebagai konjungsi, padahal kata sama bukan sebuah konjungsi. Seharusnya kata tersebut diganti dengan kata hubung yang lebih tepat yaitu kata dan untuk menunjukkan unsur yang setara atau senilai. Setelah diperbaiki, kalimat tersebut menjadi "Bencana tanah longsor membuat jalan tertutup tanah dan batu”.
Pandangan mengenai kesalahan berbahasa sangat beragam. Bagi peneliti dalam bidang bahasa, kesalahan-kesalahan tersebut merupakan hal yang menarik untuk diteliti. Namun, bagi sebagian guru kesalahan yang terjadi cenderung dibiarkan, mereka lebih mementingkan hasil dan menghiraukan kesesuaian bahasa yang digunakan siswa dengan kaidah berbahasa Indonesia. Guru seharusnya sudah mampu menganalisis kesalahan berbahasa yang terjadi di dalam pembelajaran melalui proses analisis yang mendasarkan kepada data berupa kesalahan berbahasa siswa baik tulis maupun lisan. Hal tersebut sejalan dengan pendapat Tarigan (1988,p.272), yang mengungkapkan bahwa seorang guru sudah selayaknya mengetahui cara-acara menganalisis kesalahan berbahasa dan cara memperbaiki atau meremedi kesalahan tersebut, terlebih pula guru bahasa.

Dalam kegiatan berbahasa, kemampuan berbicara merupakan salah satu kemampuan yang penting untuk dikuasai oleh penutur bahasa. Kemampuan tersebut penting untuk berkomunikasi dengan penutur bahasa yang lain. Di samping itu, kemampuan berbicara juga merupakan salah satu kemampuan berbahasa yang sangat menunjang dalam proses pembelajaran. Melalui aktivitas berbicara, seseorang dapat menyatakan pendapatnya secara lisan kepada orang lain. Hal tersebut sejalan dengan pendapat Tarigan (2008,p.16), yang mengungkapkan bahwa berbicara merupakan kemampuan mengucapkan bunyi-bunyi artikulasi atau kata-kata untuk mengekspresikan, menyatakan atau menyampaikan pikiran, gagasan, dan perasaan. Salah satu praktik nyata dalam proses pembelajaran yang dilakukan oleh siswa adalah proses diskusi. Melalui kegitan diskusi, siswa dapat bertukar pendapat dengan siswa lainnya, baik dalam kelompok besar maupun kecil untuk memperoleh kesepakatan atau pemahaman bersama akan suatu masalah tertentu.

Melalui diskusi, siswa dituntut untuk aktif terlibat dalam menyampaikan pendapat dan tanggapannya di dalam forum diskusi. 
Pada tahap ini siswa akan berusaha menyatakan pendapat yang ada di dalam pikiran mereka. Di sisi lain, siswa juga diharuskan menggunakan bahasanya sesuai dengan kaidah berbahasa yang berlaku. Hal ini tentu cukup menarik karena untuk dapat menggunakan bahasa yang baku, membutuhkan waktu yang panjang dan merupakan proses tidak mudah sehingga dituntut keseriusan dalam membina kemampuan tersebut pada diri siswa.

Banyak orang yang mahir menuangkan idenya dalam bentuk tulisan, akan tetapi masih menemui kendala pada saat menyatakan pendapatnya secara langsung dihadapan orang lain. Siswa dalam hal ini dituntut kemampuannya untuk dapat mengemukakan pendapat dan tanggapannya dalam proses diskusi di kelas. Pada saat menuangkan idenya dalam bentuk tulisan, siswa akan cenderung lebih berhati-hati dalam menggunakan bahasanya. Sedangkan pada saat menyatakan pendapatnya secara lisan, siswa cenderung spontan dalam menggunakan bahasanya. Kaitannya dengan hal tersebut, fokus kesalahan berbahasa yang hendak dijadikan objek penelitian ini akan tampak secara alami.

Pada hakikatnya kesalahan berbahasa dapat dikategorikan ke dalam kesalahan berbahasa lisan dan tulis. Setiap ragam kesalahan berbahasa memiliki kelebihan dan kekurangannya masing-masing. Alasan dipilihnya bahasa lisan sebagai fokus penelitian karena bahasa lisan cenderung lebih mudah dan berdaya guna untuk berkomunikasi. Sifatnya lebih longgar, lebih bebas dalam menggunakan diksi, dan cenderung kurang mengikuti kaidah-kaidah yang berlaku dibandingkan dengan bahasa tulis (Hastuti, 2003,p.83).

Dalam proses diskusi, banyak siswa mengabaikan kaidah yang seharusnya digunakan dalam berbahasa Indonesia. Misalnya seperti penggunaan kata yang tidak baku, pengucapan yang keliru dan sebagainya. Lebih lanjut lagi, hal tersebut cenderung tidak begitu diperhatikan oleh guru dalam penilaian pembelajaran di kelas dengan metode diskusi. Hal ini dapat pula memberikan pengaruh terhadap bahasa yang digunakan oleh siswa. Karena mengetahui penggunaan bahasa mereka tidak menjadi kriteria penilaian, siswa cenderung untuk menggunakan bahasa yang seenaknya, padahal seharusnya pada proses pembelajaran di dalam kelas dibutuhkan penggunaan bahasa yang formal. Terlebih siswa kelas VI sudah seharusnya telah memiliki kemampuan berbahasa yang penuh dibandingkan kelas di bawahnya.

Melalui penelitian ini diharapkan guru mulai menyadari dan memperhatikan penggunaan bahasa siswa, tidak semata-mata menilai kebenaran atau ketepatan gagasan siswa. Hal itu berkaitan dengan penggunaan bahasa yang baik dapat mencerminkan pemikiran seorang siswa sekaligus mengikuti kaidah berbahasa yang seharusnya diterapkan dalam lingkungan formal. Kesalahan berbahasa tidak boleh dibiarkan begitu saja, guru perlu mengetahui kesalahan yang dilakukan oleh siswanya. Sehingga guru dapat membenarkan tiap kesalahan yang dilakukan oleh siswa di dalam proses pembelajaran.

\section{METODE}

Penelitian ini menggunakan metode deskriptif. Pemilihan jenis penelitian yang digunakan disesuaikan dengan fokus masalah pada penelitian tersebut. Hal itu dikarenakan dalam penelitian kualitatif data yang akan dihasilkan lebih banyak berupa kata-kata. Sumber data dalam penelitian ini adalah siswa kelas VI SDN 1 Galagamba. Instrumen yang digunakan dalam penelitian ini antara lain lembar observasi dan alat perekam. Teknik analisis yang digunakan dalam menganalisis data kesalahan berbahasa yakni teknik analisis kualitatif. Hal tersebut disesabkan data yang diolah lebih banyak berupa kata-kata.

HASIL DAN PEMBAHASAN
A. Kesalahan Berbahasa Indonesia
Secara Fonologis dalam Proses Diskusi Siswa Kelas VI SDN 1 Galagamba 
Kesalahan berbahasa Indonesia secara fonologis yang ditemukan dalam proses diskusi siswa VI SDN 1 Galagamba terdiri atas kesalahan pelafalan karena perubahan dan penghilangan bunyi tertentu. Kesalahan pelafalan karena perubahan fonem terjadi pada pelafalan perubahan bunyi vokal dan pelafalan perubahan bunyi diftong yang meliputi kesalahan perubahan bunyi vokal [a] yang berubah menjadi bunyi [ə] dan kesalahan perubahan bunyi diftong [aw] yang tergantikan bunyi vokal [o] dan kesalahan pelafalan karena penghilangan bunyi tertentu yang terjadi pada terjadi pada penghilangan bunyi konsonan meliputi kesalahan penghilangan bunyi konsonan [h], [s] dan bunyi vokal [ə].

\section{B. Kesalahan Berbahasa Indonesia Secara Morfologis dalam Proses Diskusi Siswa Kelas VI SDN 1 Galagamba}

Kesalahan berbahasa Indonesia secara morfologis yang ditemukan dalam proses diskusi siswa VI SDN 1 Galagamba terdiri atas kesalahan penggunaan afiks yang tidak tepat dan penghilangan afiks. Kesalahan penggunaan afiks yang tidak tepat meliputi kesalahan kesalahan penggunaan prefiks ter- yang tergantikan prefiks ke-, kesalahan penggunaan sufiks -nya, kesalahan penggunaan konfiks mem-kan, kesalahan penggunaan prefiks nge-, dan kesalahan penggunaan penggunaan sufiks -kan. Kesalahan secara morfologis terjadi pada kesalahan penghilangan afiks yang terdiri atas kesalahan penghilangan prefiks ber-, dan kesalahan penghilangan prefiks me-, mem-, men-, meng-, yang merupakan alomorf dari prefiks $m e N$ -

C. Kesalahan Berbahasa Indonesia Secara Sintaktis dalam Proses Diskusi Siswa Kelas VI SDN 1 Galagamba

Kesalahan berbahasa Indonesia secara sintaktis yang ditemukan dalam proses diskusi siswa VI SDN 1 Galagamba meliputi kesalahan bidang frasa dan kalimat. Kesalahan dalam bidang frasa meliputi kesalahan penghilangan preposisi, pengguanaan bentuk superlative yang berlebihan, Kesalahan dalam bidang kalimat meliputi kesalahan akibat penggunaan istilah asing, kesalahan penghilangan konjungsi, penggunaan konjungsi yang tidak tepat, dan adanya pengaruh bahasa daerah. Adanya pengaruh bahasa daerah tersebut dikarenakan fakor kebiasaan dalam komunikasi lisan sehari-hari. Kesalahan selanjutnya karena penghilangan preposisi, yakni pada preposisi di. Kesalahan lainnya adalah penggunaan istilah asing yang terjadi pada munculnya kata game dalam kalimat yang seharusnya berbahasa Indonesia.

D. Kesalahan Berbahasa Indonesia

Secara Semantis dalam Proses Diskusi Siswa Kelas VI SDN 1

\section{Galagamba}

Kesalahan berbahasa Indonesia secara semantis yang ditemukan dalam proses diskusi siswa kelas VI SDN 1 Galagamba mencakup kesalahan pilihan kata (diksi) yang dilakukan oleh siswa dalam proses diskusi terdiri atas penggunaan kata-kata yang tidak tepat yang diakibatkan pilhan kata tidak baku serta tidak lazim digunakan misalnya kata kalo, kayak, liat, ngga, dan tipi. Kesalahan diksi menjadi kesalahan berbahasa Indonesia dengan jumlah terbanyak yang ditemukan dalam proses diskusi siswa sekolah dasar.

\section{E. Kesalahan Kohesi dan Koherensi dalam Proses Diskusi Siswa Kelas VI SDN 1 Galagamba}

Kesalahan kohesi dan koherensi yang ditemukan dalam proses diskusi siswa kelas VI SDN 1 Galagamba terdiri atas kesalahan kata ganti (pronomina), kesalahan penanda kata penghubung (konjungsi), dan kesalahan penyulihan (substitusi). Pada kesalahan kohesi yang paling banyak pada kesalahan penyulihan. Kesalahan koherensi yang ditemukan dalam 
wacana percakapan siswa terdapat pada percakapan yang tidak koheren antara guru dan siswa. Namun demikian, secara umum wacana diskusi siswa dapat dikatakan koheren walaupun terdapat beberapa penanda kohesi yang tidak dieksplisitkan.

F. Kesalahan Logika dalam Proses Diskusi Siswa Kelas VI SDN 1 Galagamba

Kesalahan logika yang ditemukan dalam proses diskusi siswa kelas VI SDN 1 Galagamba meliputi kesalahan kalimat yang tidak logis atau tidak dapat dinalar. Kesalahan logika dalam proses diskusi siswa lebih diakibatkan makna kalimat yang dibentuk oleh siswa tidak dapat diterima oleh nalar. Kesalahan tersebut dapat terjadi karena pemilihan kata yang kurang tepat dalam proposisi yang disampaikan siswa, sehingga kalimat yang dibentuk menjadi tidak logis.

\section{DISKUSI PENELITIAN}

\section{A. Tidak Mudah Berbahasa Indonesia dengan Baik dan Benar}

Berbahasa Indonesia dengan baik dan benar tidaklah mudah, butuh kecermatan dan pembiasaan untuk mencapai hal tersebut. Pengguna bahasa yang baik tentu harus memerhatikan penggunaan kaidah dalam berbahasa. Di dalam situasi yang resmi, pengguna bahasa dituntut untuk menggunakan bahasa sesuai dengan kaidah yang berlaku. Masalah akan muncul apabila pengguna bahasa tidak menggunakan bahasa sesuai dengan situasi pembicaraannya.

Kegiatan berbahasa tidak hanya perlu baik, tetapi juga harus benar dalam praktiknya. Akan tetapi, dalam penggunaannya sering kita temukan kejanggalan berbahasa terutama jika ditinjau dari segi kebahasaan. Kita sering menjumpai sebagian masyarakat yang berpendapat bahwa tujuan utama berbahasa hanya sekedar menyampaikan pesan, sehingga kaidah bahasa yang berlaku justru diabaikan. Sebagian besar masyarakat yang menggunakan bahasa cenderung kurang memedulikan kaidah berbahasanya. Mereka menganggap selama pembicara dan pendengar dapat saling memahami maksud yang sedang dibicarakan, maka pembicaraan tersebut sudah baik dan benar.

Proses belajar mengajar di sekolah merupakan salah satu contoh situasi resmi yang menuntut adanya penggunaan bahasa Indonesia dengan baik dan benar. Sejalan dengan pernyataan tersebut, Arifin dan Hadi (2001,p.12) mengungkapkan bahwa bahasa Indonesia yang baik dan benar adalah penggunaan bahasa Indonesia yang digunakan sesuai dengan norma kemasyarakatan dan sesuai kaidah bahasa Indonesia yang berlaku. Namun demikian, pada kenyataannya siswa selama berada di sekolah masih belum sepenuhnya mampu menggunakan bahasa Indonesia dengan baik dan benar. Masih banyak ditemukan beragam kesalahan berbahasa Indonesia yang dilakukan oleh siswa dalam pembelajaran di sekolah.

Melengkapi pendapat sebelumnya, Alwi, et al, (2000,p.20-21) juga mengemukakan bahwa bahasa yang benar merupakan penggunaan bahasa yang mengikuti kaidah yang telah dibakukan, sedangkan bahasa yang baik merupakan pemanfaatan ragam yang tepat dan serasi menurut golongan penutur dan jenis bahasa. Berdasarkan pendapat tersebut, dapat dikatakan bahwa bahasa yang baik merupakan bahasa yang digunakan sesuai dengan situasi pembicaraan.

Sebagai pengguna bahasa yang baik, kita sudah sepatutnya mampu menyesuaikan diri dengan lingkungan. Bahasa yang benar dapat dianggap menjadi tidak baik apabila digunakan tidak sesuai dengan situasi penggunaannya. Bahasa yang baik tidak selamanya sama dengan bahasa yang 
benar. Bahasa yang tepat sasaran tidak harus beragam baku. Berbahasa dengan baik berarti kita harus mampu menyesuaikan diri dengan situasi. Bahasa yang digunakan di lingkungan pendidikan tentu berbeda dengan bahasa yang digunakan di pasar.

Bahasa yang baik belum tentu benar, kecuali jika bahasa tersebut sesuai dengan kaidah berbahasa yang berlaku. Berbahasa dengan benar memiliki arti bahwa dalam berbahasa penutur harus mampu menaati kaidah bahasa yang berlaku. Adanya kaidah yang mengatur kegiatan berbahasa ini bukan untuk mengekang aktivitas berbahasa, melainkan untuk menjaga penggunaan bahasa tersebut tetap terbebas dari pengaruh kontaminasi bahasa daerah dan bahasa asing. Jadi dapat disimpulkan bahwa bahasa yang baik dan benar adalah bahasa yang dapat dipahami dan sesuai situasinya serta tidak menyimpang dari kaidah berbahasa yang berlaku. Bahasa yang baik dan benar dapat digunakan sesuai dengan fungsi dan situasi.

\section{B. Interferensi Sebagai Faktor Penyebab Kesalahan Berbahasa}

Bahasa bersifat dinamis oleh karena itu selalu mengalami perubahan serta pergeseran. Perubahan dan pergeseran tersebut dapat terjadi karena adanya perubahan politik, sosial, ekonomi, dan budaya. Bahasa sebagai bagian integral suatu kebudayaan tidak dapat lepas dari kontak yang ditimbulkan oleh pemakaian bahasa. Kontak karena kepentingan bidang politik, pendidikan, ekonomi, ilmu pengetahuan, dan lainnya dapat menyebabkan suatu bahasa terpengaruh oleh bahasa yang lain.

Bahasa Indonesia telah lama hidup secara berdampingan dengan bahasa-bahasa daerah. Maka, suatu kewajaran apabila terjadi proses saling memengaruhi antara bahasa Indonesia dan bahasa daerah. Proses saling memengaruhi inilah yang dikenal dengan istilah interferensi. Hal itu sejalan dengan pendapat Alwasilah (1985,p.132), yang mengungkapkan bahwa interferensi berrati adanya saling pengaruh antarbahasa. Pengaruh itu dalam bentuk yang paling sederhana berupa pengambilan satu unsur dari satu bahasa dan digunakan dalam hubungannya dengan bahasa lain.

Pada akhirnya proses saling memengaruhi antara bahasa yang satu dengan bahasa yang lain tidak dapat dihindarkan. Persentuhan kedua bahasa tersebut menimbulkan adanya kontak bahasa. Kontak bahasa dapat mengakibatkan perubahan sistem suatu bahasa yang disebabkan oleh pengambilan unsur suatu bahasa ke dalam bahasa yang lain. Mendukung pendapat sebelumnya, Wenreich (dalam Chaer dan Agustina, 2010,p.120) menyebut interferensi sebagai perubahan sistem suatu bahasa sehubungan dengan adanya persentuhan bahasa tersebut dengan adanya persentuhan bahasa tersebut dengan unsur-unsur bahasa lain yang dilakukan oleh penutur yang bilingual. Hampir setiap orang di Indonesia menguasai lebih dari satu bahasa, bahkan terdapat beberapa orang yang mampu menguasai beberapa bahasa sekaligus. Penguasaan dwibahasa atau multibahasa tidak menutup kemungkinan dapat mengakibatkan gesekan dalam penggunaan bahasa. Hal tersebut dapat mengakibatkan bahasa satu dengan yang lainnya saling memengaruhi. Akibat yang ditimbulkan dari gesekan tersebut adalah terjadinya interferensi kebahasaan. Hal tersebut sejalan dengan pendapat Suwito (1983,p.39-40) yang mengungkapkan bahwa apabila dua bahasa atau lebih digunakan secara bergantian oleh penutur yang sama, dapat dikatakan bahwa bahasa tesebut dalam keadaan saling kontak. Dalam setiap kontak bahasa terjadi proses 
saling mempengaruhi antara bahasa satu dengan bahasa yang lain.

Dalam proses belajar bahasa, memungkinkan terjadinya interferensi bahasa. Interferesi bahasa sangat sulit dihindari sehingga dapat mengakibatkan perubahan dan perkembangan bahasa. Terjadinya gejala interferensi juga tidak lepas dari perilaku penutur bahasa dan penerima. Bahasa dapat berkembang dengan cepat dan menyerap unsurunsur asing jika penutur dan penerima sering melakukan interferensi. Akan tetapi, upaya pemertahanan suatu bahasa dapat terhambat jika interferensi semakin marak dilakukan oleh para pengguna bahasa.

Berdasarkan hasil analisis terhadap proses diskusi yang dilakukan siswa ditemukan gejala interferensi dalam berbagai hal. Salah satunya interferensi secara morfologis, bentuk interferensi tersebut berkaitan dengan pembentukan kata dengan afiks. Interferensi secara morfologis yang ditemukan dalam proses diskusi terdapat pada kata kebawa, kebakar, dan ketutup. (kebawa-Jawa:kegawa; terbawa: Indonesia). Berdasarkan contoh tersebut, dapat dilihat bahwa siswa mengidentifikasi morfem bahasa daerah dan mempraktikannya ke dalam bahasa Indonesia. $\mathrm{Hal}$ itu mendukung pendapat Chaer dan Agustina (2010,p.123), yang mengungkapkan bahwa interferensi dalam bidang morfologi terdapat pada pembentukan kata dengan afiks. Afiks-afiks suatu bahasa digunakan untuk membentuk kata dalam bahasa lain.

Temuan di atas juga mendukung Mekarsari (2011,p.126), yang meneliti tentang kesalahan berbahasa pada hasil laporan wawancara siswa. Berdasarkan data yang diperoleh dalam penelitian tersebut, ditemukan bahwa kesalahan berbahasa yang dilakukan siswa terjadi pada kesalahan penghilangan afiks tertentu dan penggunaan afiks yang tidak tepat yang disebabkan adanya pengaruh morfem dalam bahasa daerah. Temuan tersebut juga mendukung pendapat Hastuti (2003,p.40) yang mengemukakan bahwa interferensi di bidang tata bahasa dapat terjadi kalau dwibahasawan mengidentifikasi morfem, kelas morfem, atau hubungan ketatabahasaan pada sistem bahasa pertama dan mempraktikannya dalam tuturannya pada bahasa kedua atau sebaliknya. Selain temuan interferensi secara morfologis, interferensi leksikal juga terjadi dalam proses diskusi siswa.

Interferensi leksikal terjadi karena siswa memasukkan salah satu kosakata bahasa daerah ke dalam bahasa Indonesia. Perbendaharaan kata suatu bahasa pada umumnya hanya terbatas pada pengungkapan berbagai segi kehidupan yang terdapat di dalam masyarakat yang bersangkutan, serta segi kehidupan lain yang dikenalnya. Oleh karena itu, jika masyarakat bergaul dengan lingkungan yang baru, maka mereka akan bertemu dan mengenal konsep baru.

Karena penutur belum mempunyai kosakata yang mencukupi untuk mengungkapkan konsep baru tersebut, maka penutur biasanya menggunakan kosakata bahasa sumber untuk mengungkapkannya. Salah satunya interferensi secara leksikal yang ditemukan dalam proses diskusi terdapat pada kata ilir. Berdasarkan contoh tersebut, dapat dilihat bahwa siswamengambil kosakata bahasa daerah sebagai padanan kata dan menggunakannnya dalam bahasa Indonesia.

Dalam hal ini, penutur bahasa
secara sengaja menyerap atau
meminjam kosakata bahasa sumber
untuk mengungkapkan konsep baru
tersebut. Faktor ketidakcukupan atau
terbatasnya kosakata bahasa penerima
untuk mengungkapkan suatu konsep
baru dalam bahasa sumber, cenderung
akan menimbulkan terjadinya
interferensi. Hal tersebut didukung


pendapat Aslinda dan Syafyahya (2007,p.73) yang mengemukakan bahwa interferensi dalam bidang leksikal terjadi apabila seorang dwibahasawan dalam peristiwa tutur memasukkan leksikal bahasa pertama ke dalam bahasa kedua atau sebaliknya.

Dengan demikian, interferensi memegang dominasi yang sangat besar sebagai penyebab kesalahan berbahasa yang dilakukan oleh siswa. Interferensi merupakan salah satu faktor penyebab kesalahan berbahasa dan dipandang sebagai pengacu karena merusak sistem suatu bahasa. Hal itu dikarenakan interferensi yang terjadi hampir pada semua komponen kebahasaan siswa. Hal tersebut sesuai dengan pendapat Suwito (1983,p.55) yang menjelaskan bahwa interferensi dapat terjadi dalam semua komponen kebahasaan, yaitu bidang tata bunyi, tata kata, tata kalimat, dan tata makna.

\section{Dominasi Kesalahan Pilihan Kata dalam Proses Diskusi Siswa}

\begin{tabular}{lcr}
\multicolumn{2}{c}{ Dalam kegiatan } & berbahasa, \\
pembicara atau penulis & hendaknya \\
memiliki kemampuan & dalam
\end{tabular} mempertimbangkan aspek pilihan kata (diksi), baik dalam bentuk lisan maupun tertulis. Pilihan kata atau diksi merupakan salah satu aspek yang penting dalam kegiatan berbahasa. Ketidaktepatan dalam menggunakan kata-kata dapat menyebabkan terjadinya kesalahan berbahasa. Kesalahan berbahasa Indonesia dalam proses diskusi terdapat pada pilihan kata tidak tepat, hal tersebut dapat termasuk ke dalam kategori kesalahan berbahasa secara semantis. Temuan tersebut mendukung pendapat Setyawati (2010,p.103-104), yang mengungkapkan bahwa kesalahan berbahasa Indonesia pada tataran semantik dapat berupa kesalahan penggunaan kata-kata yang mirip dan kesalahan pilihan kata atau diksi.
Pada saat seseorang menyampaikan gagasannya, pilihan kata yang tepat sangat diperlukan. Jika seorang pembicara kurang memerhatikan aspek pilihan kata, maka pendengar dapat menganggap pembicaraannya tidak sopan dan tidak berbobot. Kekurangmampuan pembicara atau penulis dalam memilih kata yang tepat dapat menunjukkan kemampuannya yang kurang dalam menggunakan kosakata bahasanya. Hal tersebut kemungkinan besar disebabkan oleh terbatasnya kosakata yang dimiliki oleh pembicara atau penulis.

Berkenaan dengan hal itu, tujuan utama dari pemilihan kata yakni penggunaan kata secara tepat sesuai dengan keperluan dan tujuannya. Pilihan kata juga dapat menunjukkan kualitas penguasaan kosakata yang dimiliki oleh seseorang. Hal tersebut sejalan dengan pendapat Yulianto (2008,p.84) yang mengungkapkan bahwa pilihan kata adalah mutu dan kelengkapan kata yang dikuasai seseorang sehingga ia mampu menggunakan secara cermat berbagai perbedaan dan persamaan makna kata sesuai dengan tujuan dan gagasan yang akan disampaikan, serta kemampuan untuk memperoleh bentuk yang sesuai dengan situasi dan nilai rasa yang dimiliki pembaca dan pendengar.

Penggunaan kata yang tidak tepat dalam kegiatan berbahasa dapat juga menganggu kejelasan informasi yang hendak disampaikan kepada orang lain. Hal tersebut sejalan dengan pendapat, Warsiman (2010,p.26) mengungkapkan bahwa dalam kegiatan berbahasa, pilihan kata merupakan aspek yang sangat penting untuk diperhatikan, karena pilihan kata yang tidak tepat selain dapat menyebabkan ketidakefektifan bahasa yang digunakan, juga dapat menganggu kejelasan informasi yang disampaikan.

Kesalahan berbahasa dalam pilihan kata dapat terjadi pada ragam 
tulis dan lisan. Sering kita jumpai banyak penyimpangan terjadi dalam penggunaan bahasa sehari-hari berkaitan dengan pilihan kata yang tidak tepat. Bahasa Indonesia sebenarnya memberikan kebebasan seluas-luasnya bagi penuturnya untuk memilih kata yang disukainya, memakai kata-kata yang menarik baginya, akan tetapi hal tersebut tidak berlebihan dan hendaknya tetap memerhatikan kaidah yang berlaku.

Kesalahan pilihan kata terjadi akibat kesalahan pemilihan kata-kata yang tidak tepat dalam proses diskusi siswa. Ketidaktepatan penggunaan kata atau pilihan kata dapat juga dapat disebabkan karena penggunaan kata yang tidak baku. Berdasarkan hasil analisis pada kesalahan pilihan kata ditemukan fakta bahwa siswa sering melakukan kesalahan dalam pilihan kata dengan memasukkan kata tidak baku dalam situasi pembelajaran di sekolah. Hal tersebut dapat disebabkan oleh pergaulan siswa pada kesehariannya lebih sering menggunakan kata tidak baku. Maka, tidak menutup kemungkinan bahasa pergaulan siswa menular dalam proses pembelajaran di sekolah.

Hal ini terbukti dengan banyaknya penggunaan kata tidak baku dalam proses diskusi yang dilakukan siswa. Hampir setiap siswa melakukan kesalahan pada kategori ini. Berdasarkan hasil analisis menunjukkan bahwa kebanyakan mereka tidak menyadari kalau kata ngga, tapi, dan tau sebagai ragam bahasa nonbaku seharusnya tidak boleh digunakan dalam kegiatan pembelajaran yang menuntut penggunaan ragam bahasa baku. Karena lazimnya penggunaan bahasa dalam situasi formal seperti forum diskusi dan rapat menggunakan bahasa Indonesia yang baku.

Kesalahan pemilihan kata merupakan kesalahan dengan jumlah terbanyak yang ditemukan dalam proses diskusi siswa. Hal ini mengindikasikan siswa yang belum mampu dalam memilih kata yang tepat untuk disampaikan kepada orang lain secara lisan. Kekurangtepatan dalam pemilihan kata dapat berakibat pada penilaian oleh pendengar atau pembaca bahwa pembicara atau penulis kurang mampu menggunakan kosakata bahasanya. Kekurangmampuan itu kemungkinan besar diakibatkan karena kurang luasnya penguasaan kosakata penutur atau penulis (Yulianto dan Mintowati, 2010,p.4.17).

\section{SIMPULAN}

Kesalahan berbahasa Indonesia secara fonologis yang ditemukan dalam proses diskusi siswa VI SDN 1 Galagamba terdiri atas kesalahan pelafalan karena perubahan dan penghilangan bunyi tertentu. Kesalahan pelafalan karena perubahan fonem terjadi pada pelafalan perubahan bunyi vokal dan pelafalan perubahan bunyi diftong yang meliputi kesalahan perubahan bunyi vokal [a] yang berubah menjadi bunyi [ə] dan kesalahan perubahan bunyi diftong [aw] yang tergantikan bunyi vokal [o] dan kesalahan pelafalan karena penghilangan bunyi tertentu yang terjadi pada terjadi pada penghilangan bunyi konsonan meliputi kesalahan penghilangan bunyi konsonan $[\mathrm{h}]$, [s] dan bunyi vokal [ə].

Kesalahan berbahasa Indonesia secara morfologis yang ditemukan dalam proses diskusi siswa VI SDN 1 Galagamba terdiri atas kesalahan penggunaan afiks yang tidak tepat dan penghilangan afiks. Kesalahan penggunaan afiks yang tidak tepat meliputi kesalahan kesalahan penggunaan prefiks ter- yang tergantikan prefiks ke-, kesalahan penggunaan sufiks -nya, kesalahan penggunaan konfiks mem-kan, kesalahan penggunaan prefiks nge-, dan kesalahan penggunaan penggunaan sufiks -kan. Kesalahan secara morfologis terjadi pada kesalahan penghilangan afiks yang terdiri atas kesalahan penghilangan prefiks ber-, dan kesalahan penghilangan prefiks me-, mem-, 
men-, meng-, yang merupakan alomorf dari prefiks meN-.

Kesalahan berbahasa Indonesia secara sintaktis yang ditemukan dalam proses diskusi siswa VI SDN 1 Galagamba meliputi kesalahan bidang frasa dan kalimat. Kesalahan dalam bidang frasa meliputi kesalahan penghilangan preposisi, pengguanaan bentuk superlative yang berlebihan, Kesalahan dalam bidang kalimat meliputi kesalahan akibat penggunaan istilah asing, kesalahan penghilangan konjungsi, penggunaan konjungsi yang tidak tepat, dan adanya pengaruh bahasa daerah. Adanya pengaruh bahasa daerah tersebut dikarenakan fakor kebiasaan dalam komunikasi lisan sehari-hari. Kesalahan selanjutnya karena penghilangan preposisi, yakni pada preposisi di. Kesalahan lainnya adalah penggunaan istilah asing yang terjadi pada munculnya kata game dalam kalimat yang seharusnya berbahasa Indonesia.

Kesalahan berbahasa Indonesia secara semantis yang ditemukan dalam proses diskusi siswa kelas VI SDN 1 Galagamba mencakup kesalahan pilihan kata (diksi) yang dilakukan oleh siswa dalam proses diskusi terdiri atas penggunaan katakata yang tidak tepat yang diakibatkan pilhan kata tidak baku serta tidak lazim digunakan misalnya kata kalo, kayak, liat, ngga, dan tipi.

Kesalahan kohesi dan koherensi yang ditemukan dalam proses diskusi siswa kelas VI SDN 1 Galagamba terdiri atas kesalahan penanda kata penghubung (konjungsi), kesalahan penyulihan (substitusi) dan kesalahan repetisi (pengulangan). Kesalahan logika yang ditemukan dalam proses diskusi siswa kelas VI SDN 1 Galagamba meliputi kesalahan kalimat yang tidak logis atau tidak dapat dinalar.

Hasil penelitian ini dapat dijadikan sebagai bahan evaluasi bagi guru dalam melakukan tindakan untuk memperbaiki kesalahan berbahasa yang dilakukan oleh siswa. Guru juga diharapkan agar dapat menggunakan bahasa Indonesia yang baik dan benar sesuai kaidah yang berlaku baik di dalam proses pembelajaran yang berlangsung di dalam kelas, maupun diluar kelas secara intensif. Hal ini diperlukan untuk memberikan suatu contoh yang positif bagi siswa, dalam hal menggunakan bahasa Indonesia untuk pemakaian seharihari.

\section{DAFTAR RUJUKAN}

Alwasilah, A. C. (1985). Beberapa Madhab dan Dikotomi Teori Linguistik. Bandung: Angkasa.

Alwi, H. et al. (2010). Tata Bahasa Baku Bahasa Indonesia. Jakarta: Pusat Bahasa dan Balai Pustaka.

Arends, R. I. (1997). Clasroom Instructional and Management. New York: McGraw Hill Companies.

--- (2001). Learning to Teach. (5 $5^{\text {th }}$ Ed). New York: McGraw Hill Companies.

Arifin, Z., \& Hadi, F. (2001). 1001 Kesalahan Berbahasa. Jakarta: CV Akademika Presindo.

Chaer, A., \& Agustina, L. (2010). Sosiolinguistik Perkenal Awal. Jakarta: Rineka Cipta.

Dulay, et. al. (1982). Language Two. New York: Oxford University Press.

Ellis, R. (1985). Understanding Second Language Acquisition. New York: Oxford University Press.

Hanafiah, W. (2014). Analisis Kohesi dan Koherensi pada Buletin Jumat. Jurnal Epigram, 11(2),135-152. Diunduh dari http://id.portalgaruda.org/

Hartati, T. (2010). "Pendidikan Bahasa Indonesia Sebagai Bahasa Kedua". Makalah pada Seminar Antarbangsa (Internasional) Pendidikan Bahasa Melayu Serantau, Beijing.

Hastuti, S. (2003). Sekitar Analisis Kesalaban Berbahasa Indonesia. Yogyakarta: Mitra Gama Widya.

Markhamah, \& Sabardila, A. (2011). Analisis Kesalaban dan Karakteristik Bentuk Pasif. Solo: Jagad Abjad.

Mekarsari, D.O. (2011). Analisis Kesalahan Berbahasa pada Laporan Hasil Wawancara Siswa Kelas XI IPA 2 
SMAN 3 Sidoarjo. Skripsi. Tidak diterbitkan. Surabaya: Universitas Negeri Surabaya.

Muslich, M. (2010). Garis-Garis Besar Tata Babasa Baku Babasa Indonesia. Bandung: PT Refika Aditama. M. (1994). Membina Kemampuan Berbahasa. Jakarta: PT Gramedia Pustaka Utama.

Pamungkas, S. (2012). Bahasa Indonesia dalam Berbagai Perspektif. Yogyakarta: CV Andi Offset.

Pateda, M. (1989). Analisis Kesalaban Bahasa. Flores: Nusa Indah.

Pranowo. (2014). Teori Belajar Bahasa. Yogyakarta : Pustaka Belajar.

Purnamayani, N. M. D. (2014). Analisis Kesalahan Bahasa Diskusi dalam Pembelajaran Bahasa Indonesia Siswa Kelas XI di SMA Negeri 1 Sukasada. Jurnal JPBSI, 2(1),1-10. Diunduh dari http://ejournal.undiksha.ac.id/

Putrayasa, I. B. (2009). Jenis Kalimat dalam Babasa Indonesia. Bandung: PT. Refika Aditama.

Ramlan, M. (1987). Ilmu Bahasa Indonesia: Sintaksis. Yogyakarta: CV. Karyono.

Setyawati, N. (2010). Analisis Kesalahan Berbahasa Indonesia. Surakarta:Yuma Pustaka.

Slamet, Y. (2012). Problematika Berbahasa Indonesia dan Pembelajarannya Edisi 2. Yogyakarta: Graha Ilmu.

Suwito. (1983). Pengantar Awal Sosiolinguistik: Teori dan Problema. Surakarta: Henary Offset.

Syafyahya, L., \& Aslinda. (2007). Pengantar Sosiolinguistik.Bandung: Refika Aditama.

Tarigan, H. G. (1987). Pengajaran Wacana. Bandung: Angkasa.

------. (1988). Pengajaran Pemerolehan Bahasa. Jakarta: Depdikbud. -.(1989). Pengajaran Remidi Bahasa : Suatu Penelitian Kepustakaan. Jakarta: Depdikbud. -. (2008). Berbicara Sebagai Suatu Keterampilan Berbabasa. Bandung:
Angkasa.

Warsiman. (2010). Bahasa Indonesia: Teori dan Aplikasi. Surabaya: Universitas Negeri Surabaya

University Press.

Weinreich, U. (1970). Languages in Contact. Findings and Problems. Cetakan ke-7. Paris: Mouton.

Yulianto, B. (2008). Aspek Kebahasaan dan Pembelajarannya. Surabaya: Universitas Negeri Surabaya University Press.

-.(2011). Penuntun Praktis Berbahasa Indonesia dengan Baik dan Benar. Surabaya: Universitas Negeri Surabaya University Press.

Yulianto, B., \& Mintowati, M. (2010). Analisis Kesalaban Berbahasa. Jakarta: Universitas Terbuka.

Yuniseffendri. (2007). Analisis Wacana. Surabaya: Lembaga Penerbit FBS Unesa.

Zaenal, E. Z., \& Tasai, S. A. (2010). Cermat Berbahasa Indonesia. Jakarta: Akademika Pressindo. 